\title{
資型料 \\ ヨシノボリの記憶力に關する一考察
}

弘前大学交理学部生物学敉室 佐 藤 光 崔

魚類の攝食性と後脳部との相鍳々係を調べる鹞に数種の淡水魚を飼育中に，ヨシノ ボリガ肵謂 surface-feeder で，慨を主として視覚によつて発見する事を知つた。 この事から饵のかわりに何か他のもの例えば脫脂綿の小塊を投下しても, 恐らくこれ に近付いてロ中に大れるに違いなくこれを反復すれば，かかる行動は次第に減少し， ここに訓練による㹞謂記憶のようなものか汧成されるものではあるまいかとの予想の 下に以下の観察を試みた。ここに云う記憶は，無意識的自働的な反志から発生する程 度の低いものである事は云う迄もない。

用いた材料は当市の小川から得た体長 4-5 糎の個体で, 飼育中はミミズを餌とし て与えた。此樣に飼いならした個体 10 匹づつ安, 內径約 21 糎, 深さ 12 糎のバッ トに大れ集団として観察した。從つて各個の魚で行う実験結果とは異る所が多いのは もちろんの事で，決定的な結論は更らに観察を続行した後でなければ下し得ない。い づれ続報に於て詳しく述べたいと思らが，とりあえず集団で行つた結果をここに報告 する次第である。な挘集団は 3 個で，夫々No.1，2，3 と番号づけて区別した。しか し各集団で得られた結果には著しい差異ぶ認められなく, 集団の成員定換えても大差 がなかつた。

\section{憼察の方法及びその結果}

この観察は昭和 23 年 4 月 9 日より 6 月 17 日迄行つたもので，その間の水溫は本均 15 度であつた。しかし 4 月 12,13 の闻日は水溫 8 度迄下り, 魚の行動が不活潑だつ たので除外した。先づ予備観察として長さ 3 ミリ幅 1.5 ミリ（慨として与えるミミズ の小片と畧々同大）の脫脂綿を蒸溜水にひたし，ピンセットでつまんで各バットに靜 かに投下してみた。すると魚は直ちに眼で発見して喰いついた。るちろん䁩下される 事なく綿の小片は吐き出されたが，予想が適中したので，上記のよらな綿の小片を多 数作り，それを 1 個づつ約 10 秒の間隔を置いて次から次と 10 個与え，その間に魚が 喰いつく度数を記錄して,これを「1国の観察」とした。投下した綿は，最後のもの が底汽落ちた後直ちにピンセツトで靜かに全部拾いあげられた。德は大抵落下の途中 にある綿に喰いつくが，底部にあるものをロに入れる場合もある。又同一の綿を 2 匹 の魚が同時に口にする事もあり，この場合は度数を 2 として記錄した。な和綿は每回

3 糎位のシマミミズを小片にして，各バットに1日10 数個を与えた。從つて魚 は満腹狀況にはなかつた。 
新しいものを用いた。

以上のような「1回の観察」を1日に数度色々な間隔をもつて繰り返し，此樣な訓 練を殆んど每日行つたので岁る。その結果を，1 日に於ける訓練経過と，此等の訓練 の重つた日々の経過とに分けて述べると以下のようになる。

I 1 日の訓練經過「1回の観察」を10 分の間隔を置いて数回繰り返して行つ た場合の喰いつきの度数は, 大体次のような経過をとつて減少の傾向宗示す。郎ち 1 回目 10,2 回目 6,3 回目 6,4 回目 4,5 回目 1,6 回目 2,7 回目 1 ( 4 月 10 日, 水 溫 16 度，集団 1 )。これは訓練開始第 2 日目の観察記錄で，慨は観察の30 分前に与

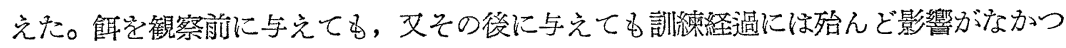
た。上の例から分るように, 訓練を 4 回位重ねると, どの集団に於ても喰いつきの度 数は非常に少くなり，以後は綿に対して殆んど反応を示さなくなる。

次に「1回の観察」を30 分置きに繰り返した一例を挙げると，1回目 8,2回目 3 , 3 回目 1,4 回目 2,5 回目 1,6 回目 1,7 回目 2,8 回目 0,9 回目 1,10 回目 1 ( 4 月 15 日, 水溫 15 度, 集団 3 ）のような経過定示して, 矢張り喰いつきの度数は漸次減 少する。間隔を 60 分にして以上のような観察を繰り返してる喰いつきの度数は減少 するが，この場合には不規則的で，或る程度減少した後に度数が急に堌加する事もま つた。60 分以上の間隔を特くと綿に対する反応が目立つて不規則となり，訓練を 10 回以上重ねないと喰いつきの度数が減少しない。

以上の結果からヨシノボリは訓纝によつて, 綿を識別出来るようになると云い得よ ら。それを支持する他方の証拠としては，綿に対して殆んど反応を示さなくなつた時 にミミズの小片を与えると，魚は例外なく喰いついて来る事である。更らに，反応を 示さなくなる迄に綿に対して訓練された集団に；綿と罟々同大の赤色の毛糸片を綿の 訓練の直後に静かに投下してやると，顯著に区応する場合がある。その一例を示せば 30 分の間隔をもつて綿に対して訓練し，1回目 9,2 回目 6,3 回目 4,4 回目 3,5 回 目 2, 6 回目 0,7 回目 1,8 回目 0 と減少した直後に 10 個の赤色毛糸学投下したとこ ろ喰いつき度数 6 を記錄した（4月14日，水溫12 度，集団 3 )。しかし赤色毛系に対 して殆んど反応しない場合もまるのでここの点に就いては更らに調查孛続けたいと思 つて居る。

II 日々の訓練經過 前述の1日に於ける観察結果から，30 分以內の間隔学置いて 約 10 回訓練を繰り返す事が最良と思われたので，4月 20 日から每日此のような訓練 を行い，每日の第1回目の訓練に於ける喰いつき度数が日を重ねるに從つて減少する ものか否かを比較記錄してみた。次の表が結果の一部である。

この観察中 4 日から14 日汽は、ミズを与えたが, 17 日から25 日迄は慨定全く与え 


\begin{tabular}{|c|c|c|c|c|c|c|}
\hline 月 & 日 & 度 数 & 月 & 日 & 度 & 数 \\
\hline V & 4 & 8 & $\mathrm{~V}$ & 17 & & 5 \\
\hline " & 5 & 6 & " & 18 & & 1 \\
\hline$" 1$ & 6 & 3 & "I & 19 & & 3 \\
\hline$" 1$ & 7 & 5 & " & 20 & & 0 \\
\hline$"$ & 8 & 3 & " & 22 & & 2 \\
\hline " & 9 & 2 & "I & 23 & & 1 \\
\hline " & 10 & 3 & "1 & 24 & & 1 \\
\hline " & 11 & 2 & $" 1$ & 25 & & 0 \\
\hline " & 13 & 5 & \multirow{2}{*}{\multicolumn{4}{|c|}{ （水溫の平均 16 度, 集団 3 )。 }} \\
\hline " & 14 & 3 & & & & \\
\hline
\end{tabular}

ずに訓練しだ。上の結果から, 喰いつきの度数が日数の䋊過につれて減少する傾向が 椝がわれる。しかしこの傾向は固定的なるのでなく，訓練を2 日も休むと綿に対する 反応が目立つて来る。その一例は上の表に於ける14日と17日の度数にも現われて居 כ。 HERRICK, C. J. (On the phylogeny and morphological position of the terminal buds of fishes. J. comp, Neurol. 1903, 13.) ( A Ameiurus 代於て 綿と餌とを用いて，接触感と味覚の識別訓練を行い，数遇後にはたとい訓續を数日休 んでも綿に対しては殆んど反応しないと報告して居るが，ヨシノボリの場合ではその 稳な傾向はみられなかつた。

以上の結果は実験裝置らしいもの疍用いずに行つた不完全なもので, 検討ゔべき個 所が非常に多い。集団として観察した篇，個々の魚の場合と相当違つた結果が現ふれ て居るが、ここに得られた結果に就いて総括すれば,

1.ヨシノボり surface-feeder で慨を主として視覚によつて発見する。

2.飭のかわりに綿の小片を朋いてもこれに飡いついて来るが，喰いつきの度数は， 30分以內の間隔を置く訓練を数回 1 日に繰り返せば次第に隇少する。旣ち綿它識別す るようになる。

3.この傾向は日を重ねて訓練を行う尌によつて强められるも, 固定的なものでなく， 2 日以上訓鍊を休もと变動してくる。

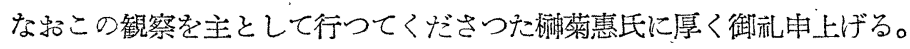

(1949 年 2 月 28 日原稿受附)

* 餌の影響に就いては後報に於て述べたい。 